\title{
The dialectics of media's role in the public sphere
}

\author{
- Jae-won Lee \& Leo W. Jeffres
}

There's an implicit assumption that the mass media, by definition, have something to do with the functioning of public in democracy. It is especially the case with the public-service media which would equate serving the public to speaking for the public. The private media are also under pressure to incorporate citizens as actors in the production of their editorial contents. The logic here is the point that, though private in ownership, these media institutionally benefit from the maximum privilege of the speech- and press-freedoms that most societies stipulate in their constitutions. Also noted in this logic is the view that the media are arguably a critical agent of information nurturing an informed citizenry, a prerequisite to fostering consolidation of democracy (Diamond, 1999).

In the field of mass communication studies, indeed the concept of public sphere has been made a sophisticated territory as evidenced in the array of related concepts such as biosphere, geosphere, noosphere, civil society, global public settings, and most importantly citizens' empowerment (McChesney, 1999). All these concepts and more have already been thoroughly articulated twice at the beginning of this new millennium in a grand staging of the U.N.-sponsored WSIS (World Summit on Information Society), but nothing substantive to the conduct of the world's news media came out of it yet (Hamelink, 2006).

As the constituent concepts of public sphere are stretched thus far, as in the case of citizens' empowerment, one has to wonder if the articulation of public sphere would have any impact at all to the media institutions while the management of the media is effectively ignored or downplayed, especially about its primary reason for existence, namely money-making. The proponents of public sphere of this direction may function as a watchdog of the watchdog media-an invaluable service in an era of shrinking media plurality--but watchdogging is not same as

Bodhi, 3 (1), 1-9. ISSN 2091-0479. (C) 2009 Kathmandu University 
managing, a vital process that ensures existence and survival of the media as a business and institutional entity. This is to say that the polemics on the media's role in society are prone to become mere rhetorics to the deaf ears of the key stakeholders. As long as the management sits behind the driving wheel, it would be much more productive and efficient if the management itself embraces initiatively and affirmatively a workable philosophy on media's vital function in society, by going beyond the self-evident aim of profit maximization. Here lies our view that some dialectics of competing concepts would be a heuristic approach to upholding media's role at the betterment of society. To this end, in this paper we will focus on some key issues of news media's role perceptions as one plausible answer to the continuing chasm between publicsphere ideals and media's business imperatives.

\section{Media's affirmative measures}

The mass-media institutions these days are being sold, merged, acquired and regrouped in a continuous cycle of transformation. Eighty-four Pulitzer Prizes and 14 Pulitzer Gold Medals for Meritorious Public Service didn't weigh very much to the Knight-Ridder group, America's second largest publisher (Connell, 2006). This group of 32 papers was sold out in the spring of 2006. Even though the papers registered a decent level of profits, they had been pushed to increase their shortterm profit margins further. In the case of publicly traded news companies, their chain owners often forge partnerships with conglomerates whose executives eventually control the running of the mass media. And, then, there follows layoffs, downsizing, and often consolidation of media outlets. The avenues of voices grow smaller in number and narrower in space. And often the real owners remain faceless in the intricate deals of chains eating up other chains.

In this climate, the head of the U.S. Society of Professional Journalists (SPJ) recently presented a desperate plea that journalists now will have to try to "defeat a force as powerful as

Bodhi, 3 (1), 1-9. ISSN 2091-0479. (C) 2009 Kathmandu University 
Wall Street" by joining them. He suggests that newspeople should "buy media stocks" because stock owners can raise their voice toward the company executives (Carlson, 2006). In fact, there are a few media institutions that even encourage their employees to own company stocks, but this road isn't likely to be any measurable impact on efficacy or become an industry trend at all. Newspeople traditionally haven't been known for their business acumen.

To be fair, there are several affirmative and initiative measures that the media themselves have been taking in an effort to embrace the public in some substantive ways. For one, many institutions conduct readership surveys or viewer polls. Values of this measure are notoriously pronounced in the case of television networks' ratings surveys, whose outcomes were often killing less-watched public-service programs. Some other media operate what they call community editorial boards. Such boards being largely advisory, they haven't yet demonstrated any particular benefits in a meaningful and visible manner. The ombudsperson mechanism, though limited in number, has been somewhat visible, with some media calling such staff public editor or reader representative. Whatever their title is, such staff persons often end up playing the role of after-the-fact apologists at most.

Many countries operate press councils or press arbitration committees. Here again, mostly the powerful of the society who are accustomed to dealing with bureaucracy tend to be the effective users of the mechanism. Yes, there are the ubiquitous letters-to-the-editors columns. Such letters, again, are subject to editors' selection and editing. They are by and large a feedback route from the public, not a proactive input measure. All these measures are better than nothing, at most, but they fall short of making the public a substantive partner to editorial or programming decisions. For the cause of media plurality, there are alternative media of various shades, but here again these alternative media more likely are nothing but a secondary fiddle while the established media command the first violin section.

Bodhi, 3 (1): 1-9. ISSN 2091-0479. (C) 2009 Kathmandu University 
Perhaps the most notable in the media's embracing of the public would be the recent trend known as public journalism or civic journalism (Kettering Foundation, 1997; Merritt, 1995; Rosen and Taylor, 1992). The legendary and highly respected American television anchor Walter Cronkite used to pride that he didn't vote in presidential elections for fear of contaminating his politics reporting. Compared to such stony detachment, public journalism is a major shift in media's role performance for its engagement and connectivity endeavor. In practice, however, public journalism surfaces as a civic engagement in a selective mode of operation that rather raises a fundamental question about journalism's basic tenet-isn't all journalism always public in form and shape anyway?

\section{Media's role-taking}

It's not difficult to attribute the emergence of public journalism as a school to the age-old behavior of the traditional media, especially to their relative insensitivity to the "public" aspects of their markets. Far too long, the news media have relied on the seemingly plausible argument that they need to be profitable first in order to be able to serve the public better. Consequently, the media indeed got rich by all measures, but democracy remains poor, as evidenced by the continuing trend of "vanishing voters," for example (Joan Shorenstein Center, 2000). "Democracy without citizens" is being talked about as if it is not a self-contradiction as a concept (Entman, 1989). "Deliberative opinion poll" is being proposed as a new polling method as if public opinion had been possible without deliberation occurring among citizens (Fishkin, 1995). All these related developments point fingers at the news media for weaknesses and shortcomings in their role performances.

The "dialectics of media's roles," in our conception, is a plea and wish that the media themselves embrace a broader view of their role in society. One concrete measure would be treating the people the news media serve as a multidimensional construct. The media make a lot of assumptions in serving the

Bodhi, 3 (1), 1-9. ISSN 2091-0479. (C) 2009 Kathmandu University 
people as to the people's needs, wants and preference. They want more sports pages; they want to hear about celebrities; they like to read about pet animals; if so, the media would take these as anticipations and will strive to provide gratifications accordingly. Instead of this wants-dictated conception of the people the media serve, how about taking the people as a multilayered construct of not only wants but also needs?

Table 1: General typology of people in the media's conception

\begin{tabular}{|l|l|l|l|}
\hline Typology & Collectivity & $\begin{array}{l}\text { Setting/ } \\
\text { Environment }\end{array}$ & $\begin{array}{l}\text { Primary } \\
\text { Objectives }\end{array}$ \\
\hline $\begin{array}{l}\text { Human } \\
\text { beings }\end{array}$ & Mankind & $\begin{array}{l}\text { Global civil } \\
\text { society }\end{array}$ & Humanity \\
\hline Citizens & Public & $\begin{array}{l}\text { Community/ } \\
\text { Nation state }\end{array}$ & $\begin{array}{l}\text { Participatory } \\
\text { democracy }\end{array}$ \\
\hline $\begin{array}{l}\text { Clients/ } \\
\text { customers }\end{array}$ & Audience & Market & Profits \\
\hline
\end{tabular}

What the people are in the media's conception provides much of the bases upon which the media develop and retain their assumptions. This way, they also project anticipations. The schema shown in Table 1 summarizes the general typology of people in the media's conception: People might be seen as taking three different layers of entities-as clients or customers in a business market at one level, as citizens constituting a public in society at another level, and as human beings in a global civil society at still another level. It is apparent that the news media today tend to treat people primarily as business customers, less frequently as citizens in democracy, and only occasionally as human beings having equal rights to humanity wherever they reside (Lee, 2001).

The schema shown here could be a guide for the news media in conducting their business and generating contents. It could serve as a frame in which news could be developed, too. The repertoire of news information could be much broader and richer if people are seen as more than mere commercial clients. The media's role-taking in society is bound to be much more

Bodhi, 3 (1): 1-9. ISSN 2091-0479. (C) 2009 Kathmandu University 
conducive to the public-sphere ideals, too. And, ironically, media's playing field looms larger than the retail market of a narrower vision. If the media's big-business approach is done along the line of the schema here, it would be the old-fashioned way of making money-"We earn it," as one ad line of a financial firm used to say.

\section{News as subjectivity objectified}

Another concrete measure that we see wanting in the news media's operation is a re-conceptualization of their cardinal principle of objectivity in news reporting. Equating news to truth value has been the media's convenient shield against credibility issues, but in reality journalism has been a subjective endeavor all along in many of its essential tenets. Its practice always involved selection of important items, judgment over newsworthiness, human processing of information, assessment of news values, and consideration of fairness, impartiality and balance. In all these facets, the so-called objective reporting has rather been relevant to how-to-report techniques than to what-to-report substance.

It is no wonder there is no shortage of literature that reveals, examines and decries the inadequacy of objectivity as the ruling ideology in professional journalism (Fallows, 1997; Gans, 1979; Sabato, 1993; Tuchman, 1978). As long as the news media tout objectivity as their primary tenet in news, objectivity will continue to be a generalized expectation that the people will demand to see it practiced as promised. It's an expectation that's almost impossible to be fulfilled in this world of complex realties, hence its futility as a major hallmark or organizing principle of news.

How about embracing a theoretically valid, empirically proven and practically heuristic concept as journalism's guiding principle? Here, let's consider the merit of what could be termed "subjective journalism." In suggesting this term, we think of news as value-added commodity produced through the

Bodhi, 3 (1), 1-9. ISSN 2091-0479. (C) 2009 Kathmandu University 
process of subjectivity objectified. Subjectivity means contextual perspective, relevant knowledge and insights, appropriate level of information, and experience on the subject in the given field (Lee, 2001). The objective part in this conception is the journalism's professional routines and techniques-i.e., checking accuracy, how to quote, whom to attribute to, verifying records, etc.

Before assigning objectivity to partnership with subjectivity, we feel it's only fair to give credits to its contribution, an extensive one, to the profession of journalism for its operationalization of the ideal. Such operationalization led to the establishment of a set of standards and conventions for journalistic practices, as seen in the SPJ Code of Ethics, to name but an example. Such standards have made journalism behave as a profession and be respected as such. This way, objective reporting has helped professionalize the practice of journalism.

But the problem lies in that such professionalization is now stifling the very subjectivity in the course of objectification, as evident in such consequences as news conformity or standardization of news. Further, in the current objective reporting tradition, the advantage of advocating one's point of view lies with the party that's capable of promoting or advocating its side or with the sources of "official news" that tend to carry conventional legitimacy (Glasser, 1992; Sigal, 1973).

It seems about time to put "human faces" on the mechanical process of objectivity (Ward, 1999), or try, in our terms, a dialectic objectification of subjectivity-better yet, subjectivities of many shades and forms - as a guiding post of today's journalism. This dialectic role-taking is a fine balancing act, for sure, but it's the necessary first step to connecting news to the reporter, the reporter to the public, and the public to the media. Ken Auletta (2006) asks "whom do journalists work for," and he gives the dialectic answer-they

Bodhi, 3 (1): 1-9. ISSN 2091-0479. (C) 2009 Kathmandu University 
work for them all, the public as well as the publisher, hence his reluctant advice to the journalists: "Be prepared to be fired."

\section{References}

Auletta, K. (2005). Whom do journalists work for? The Red Smith Lecture in Journalism. University of Notre Dame, Notre Dame, Indiana.

Carlson, D. (2006). Don't let quest for profits co-opt the news media. Quill, May issue, p. 3.

Connell, C. (Ed.) (2006). Journalism's crisis of confidence: A challenge for the next generation. New York: Forum on the Future of Journalism Education, Carnegie Corporation of New York.

Diamond, L. (1999). Developing democracy: Toward consolidation. Baltimore: Johns Hopkins University Press.

Entman, R. M. (1989). Democracy without citizens: Media and the decay of American politics. New York: Oxford University Press.

Fallows, J. (1997). Breaking the news: How the media undermine American democracy. New York: Vintage Books.

Fishkin, J. S. (1995). The voice of the people: Public opinion and democracy. New Haven: Yale University Press.

Gans, H. J. (1979). Deciding what's news. New York: Vintage Books.

Glasser, T. L. (1992). Objectivity and news bias. In E. D. Cohen (Ed.), Philosophical issues in journalism (pp. 176-185). New York: Oxford University Press.

Hamelink, C. J. (2006). Could the WSIS have been different? IAMCR Newsletter, 16 (1), 7-8.

Joan Shorenstein Center on the Press, Politics, and Public Policy. (2000, April 27). Public Involvement and the 2000 nominating campaign. A report of the Vanishing Voter Project, Harvard University.

Bodhi, 3 (1), 1-9. ISSN 2091-0479. (C) 2009 Kathmandu University 
Kettering Foundation. (1997). Speaking of public journalism. A report from the Project on Public Life and the Press (American Press Institute), Dayton, Ohio.

Lee, J. (2001). News and reality: A paradigmatic manifesto for subjective journalism. In L. Manca \& G. W. Pieper (eds.), A Heretic in American Journalism Education and Research: Malcolm S. MacLean, Jr., Revisited (pp. 74, 91-98). Columbia: University of Missouri, Stephenson Research Center.

McChesney, R. W. (1999). Rich media, poor democracy. Urbana: University of Illinois Press.

Merritt, D. (1995). Public journalism and public life. Hilldale, NJ: Erlbaum.

Rosen, J., \& Taylor, P. (1992). The new news vs. the old news. NewYork: Twentieth Century Fund Press.

Sabato, L. J. (1993). Feeding frenzy. NewYork: Free Press.

Sigal, L. V. (1973). Reporters and officials. Lexington, MA: D. C. Health and Co.

Tuchman, G. (1978). Making news: A study on the construction of reality. NewYork: Free Press.

Ward, S. (1999, May 3). Pragmatic news objectivity: Objectivity with a human face. Discussion paper D-37 of Joan Shorenstein Center of the Press, Politics, and Public Policy, Harvard University.

Bodhi, 3 (1): 1-9. ISSN 2091-0479. (C) 2009 Kathmandu University 